\title{
THE IMPACTS OF STIMULATION IN PROTRACTED LABOR TO CORTISOL LEVELS AND INCIDENCE OF POST-PARTUM BLUES
}

\author{
Soetrisno, Supriyadi Hari Respati, Sri Sulistyowati, Hendro Kurniawan \\ Department of Obstetrics and Gynecology, Faculty of Medicine, Sebelas Maret University, \\ Dr. Moewardi General Hospital Surakarta
}

\begin{abstract}
ABSTRAK
Tindakan persalinan, induksi, stimulasi, seksio sesarea dan dengan bantuan alat misalnya vacuum extraction, dapat mengurangi kepercayaan ibu atas lancarnya proses persalinan, serta meningkatkan stress postpartum. Stresor ini merangsang HPA axis (Hipothalamus-Pituitary-Adrenal), sehingga kortek adrenal memproduksi hormon kortisol berlebihan, dengan akibat postpartum blues meningkat. Tujuan penelitian ini adalah menganalisis pengaruh stimulasi persalinan pada partus tak maju terhadap kadar hormon kortisol dan kejadian post partum blues. Penelitian ini merupakan penelitin eksperimental non random post test kontrol group. Subyek penelitian 30 pasien in partu diambil secara sampling berurutan, terbagi 2 kelompok (persalinan normal dan stimulasi) setiap kelompok 15. Terhadap kedua kelompok, postpartum diperiksa kadar kortisol serum, lima hari kemudian dilanjutkan pengukuran kejadian postpartum blues. Analisa statistik dengan uji-t untuk menguji perbedaan kadar cortisol dan chi square untuk menganalisis pengaruhnya terhadap kejadian post partum blues $(a=0,05)$. Mean kadar kortisol persalinan stimulasi

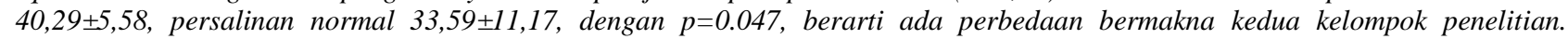
Persalinan stimulasi meningkatkan kejadian post partum blues 5,50 kali dibandingkan persalinan normal $(O R=5,50$ dan $p=0,028)$.

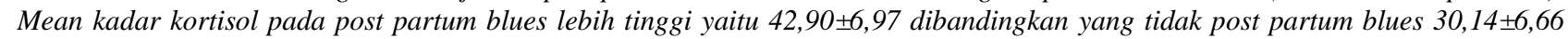
dengan $p=0.00$, yang berarti ada perbedaan bermakna kedua kelompok. Sebagai simpulan, ada peningkatan bermakna mean kadar kortisol dengan kejadian postpartum blues pada kelompok persalinan stimulasi dibanding normal.(FMI 2017;53:7-11)
\end{abstract}

Kata kunci: kadar hormon kortisol, postpartum blues, persalinan stimulasi

\begin{abstract}
Delivery, induction, stimulation, cesarean section with the aid of a vacuum extraction, for example, can reduce maternal confidence on the smooth delivery process, as well as improve postpartum stress. These stressors stimulate the HPA axis (hypothalamuspituitary-adrenal), so that the adrenal cortex produces more cortisol hormone, it can increase postpartum blues. The objective of this study was to analyze the effect of delivery stimulation on protracted labor on cortisol levels and the occurrence of postpartum baby blues. This was an experimental study of non-randomized post-test control group. The subject of the study 30 patients in labor taken consecutive sampling, divided into 2 groups (normal delivery and stimulation) each group consist of 15 patients. In stimulation delivery group, it is examined of cortisol serum levels after five days and then continued for postpartum blues occurrence measurement. Statistical analysis using t-test for differences in levels of cortisol and chi square for analyzing the effect on the occurrence of post-partum blues $(a=0.05)$. Mean level of cortisol in delivery stimulation group is $40.29 \pm 5.58$, in normal delivery is $33.59 \pm 11.17$, with $p=0.047$, meaning there are significant differences both study groups. Stimulation delivery increases the occurrence of post-partum blues 5.50 times compared to normal delivery (OR=5.50 and $p=0.028)$. Mean cortisol levels on postpartum blues higher at $42.90 \pm 6.97$ compared to no post-partum blues $30.14 \pm 6.66, p=0: 00$, which means there are significant differences both groups. In conclusion, there was significant relationship between stimulation in protrated labor that increases cortisol serum level and post partum blues incidence. (FMI 2017;53:7-11)
\end{abstract}

Keywords: cortisol hormone levels, postpartum blues, stimulation delivery

Correspondence: Soetrisno, Department of Obstetric and Gynecology, Faculty of Medicine Sebelas Maret University, Surakarta, Indonesia. Phone: 0816672564. e-mail: soetrisno_spogk@yahoo.com

\section{INTRODUCTION}

The process of childbirth induces both major physical and psychological changes in women. Physiological changes of the mother may also cause psychological changes. These changes include tightness, worry, fear, panic and irritability which comes from having to face changes in body image, having to respond to baby's crying or general worry about the baby's health. Being a mother also means having to let go of her old identities as a young woman, teenager and also as a child, replacing those identities with one full of responsibility (Marshall, 2004). After labor, a woman is expected to know how to take care and nurture her child well. This great responsibility often burdens many women to 
undergo psychological changes after labor known as post-partum blues (Suhemi, 2009).

Some cases of labor aren't progressing normally and need labor augmentation, these include protracted labor, serotinus, severe preeclampsia (PE), premature rupture of membrane (PROM), etc. The augmentation procedure could increase psychological stress of the patient with adverse psychological effects, one of them is postpartum blues. Post-partum blues is a kind of adaptation disturbance with onset beginning at first to fourteenth day after labor, commonly the symptoms are most evident at the fifth day (Reeder, et al.,1997).

The study by Hansen and Jones in America in Bobak (1994) discovered that $75-80 \%$ of mother will experience post-partum blues. Although currently postpartum blues is regarded as normal in women who are adapting to her new role as a mother, in which the symptoms will disappear within few days after labor, some women will have progressive worsening of symptoms which develops to post-partum blues depression. Daw and Steiner in Bobak (1994) reported that the incidence of post-partum depression vary from $5 \%$ to $25 \%$ of all inadequately treated post-partum blues.

In Indonesia, almost $70 \%$ of new mothers will experience post-partum blues. Most mothers will recover within less than two weeks, but $13 \%$ will experience post-partum depression (Shinaga, 2006). When post-partum depression was recognized, appropriate care with involvement of a psychiatrist needs to be given (Suhemi, 2009). Handerson (2007) and Curry (2008) found that labor intervention, including labor induction, stimulation and assisted with equipments could increase patient's post-partum stress level, lower patient's trust and also increase the rate of post-partum blues.

Beside stimulated induction, the rate of post-partum blues is also increased with failure of adapting into the role of a mother in the stages including pregnancy, childbirth and after childbirth (Handerson, 2007). According to Shinaga (2006), a woman undergoing pregnancy and childbirth need to adapt to the possibilities of life changes due to the process of pregnancy and the life after childbirth. Increasing incident of post-partum blues in mothers who were stimulated in labor has not been able to be explained in detail, especially regarding the biomolecular and hormonal aspects. This study aims to explain the biomolecular and hormonal aspects, especially the role of cortisol in postpartum blues of patients with stimulated labor.

Labor stimulation is potentially a stressor which could alter psychological perception of post-partum patients.
Stressors could also come from the conditions of the delivery room (Curry, 2008). In its classical pathways, the hypothalamus-pituitary-adrenal (HPA) axis will respond to stressors, ultimately result in the production of cortisol which may have an important role in postpartum blues.

Labor stimulation involves unnatural continuous contraction of the uterus, this will cause the head of the fetus to oscillate up and down in its route to labor, which cause increased pressure of the cervix. This condition will induce the posterior hypophysis to produce more oxytocin, which further excite uterine wall contraction and cause considerable pain. The pain is also a stressor which induces the activation of the HPA axis (Curry, 2008).

This study aims to learn about the cortisol level in women who gave birth with assisted stimulation in protracted labor compared to normal labor. The results of this study hopefully could give a representative view of women's mental status after labor as a basis of psychological intervention which may be needed by women after childbirth, especially those with stimulated labor.

\section{MATERIALS AND METHODS}

This was a non-randomized experimental study with post-test controlled group. The setting of the study was the ward and polyclinic of RSUD DR. Moewardi Surakarta and the PRODIA laboratory in Surakarta and Jakarta, Indonesia.

The subjects of the study were 30 inpartu patients, collected by consecutive sampling. The subjects were divided into two groups (normal labor and stimulated labor), each group consists of 15 subjects. The inclusion criteria for this study were women 20-35 years old, normal and stimulated labor indicated by protracted labor, pregnancy of 37-41 weeks, no depression history, primipara and with APGAR score $>7$. The exclusion criteria were the Lie Scale Minnesota Multiphasic Personality Inventory (L-MMPI) score of > 10, pregnancy with complications (preeclampsia, placenta previa) and the existence of major congenital abnormalities. After all subjects signed an informed consent and the study was approved by the Ethics Committee of UNS Faculty of Medicine in Surakarta, we performed examination on the cortisol level of post-partum in PRODIA laboratory, five days afterwards the subjects were given L-MMPI questionnaire and continued with post-partum blues questionnaire. 
Data from the two groups were then analyzed with version 19 statistical package for the social sciences (SPSS) program for Windows. Statistical analysis used in this study was t-test to analyze the differences in cortisol level and chi square to analyze its effects on incidence of post-partum blues $(\alpha=0,05)$.

\section{RESULTS}

Table 1. Characteristics and homogeneity test of subjects

\begin{tabular}{lccc}
\hline \multicolumn{1}{c}{ Characteristics } & $\begin{array}{c}\text { Labor } \\
\text { Induction }\end{array}$ & $\begin{array}{c}\text { Normal } \\
\text { Labor }\end{array}$ & $\mathrm{p}$ \\
\cline { 2 - 3 } & $\mathrm{N}(\%)$ & $\mathrm{N}(\%)$ & \\
\hline Education & $9(30)$ & $9(30)$ & 0.854 \\
Elementary-Junior high school & $6(20)$ & $6(20)$ & \\
Senior high school -College & $15(50)$ & $15(50)$ & \\
& & & \\
Salary & $8(27.7)$ & $9(30)$ & 0.470 \\
$<1$ million & $7(23.3)$ & $6(20)$ & \\
21 million & $15(50.0)$ & $15(50)$ & \\
& & & \\
\hline
\end{tabular}

From table 1 above can be observed that both normal labor group and labor induction group have homogenous characteristics.

Table 2. Analysis of t test comparing cortisol level of normal and stimulated labor

\begin{tabular}{lccc}
\hline \multirow{2}{*}{ Labor } & \multicolumn{2}{c}{ Cortisol } & $\mathrm{P}$ \\
\cline { 2 - 3 } & Mean & SD & \\
\hline Stimulated & 40.29 & 5.58 & 0.047 \\
Normal & 33.59 & 11.17 & \\
\hline
\end{tabular}

The table 2 above showed that the mean of cortisol level in stimulated labor was higher $(40.29 \pm 5.58 \mathrm{ug} / 100 \mathrm{ml})$ compared to normal labor $(33.59 \pm 11.17 \mathrm{ug} / 100 \mathrm{ml})$ with $\mathrm{p}=0.047$.

Table 3. Chi square analysis of post-partum blues incidence in normal and stimulated labor

\begin{tabular}{lcccc}
\hline \multirow{2}{*}{$\begin{array}{c}\text { Post-Partum } \\
\text { Blues }\end{array}$} & \multicolumn{2}{c}{ Labor } & OR & P \\
\cline { 2 - 3 } & Stimulated & Normal & & \\
\hline Present & $11(36.7 \%)$ & $5(16.7 \%)$ & 5.500 & $0.028^{*}$ \\
Not present & $4(13.3 \%)$ & $10(33.3 \%)$ & & \\
\hline Total & $15(50.0 \%)$ & $15(50.0 \%)$ & & \\
\hline
\end{tabular}

From the table 3 above, it was shown that stimulated labor increased the risk of post-partum blues 5.50 times compared to normal labor. This was statistically meaningful with $\mathrm{p}=0.028$.

The table 4 above showed that the mean of cortisol level in post-partum blues was higher $(42.90 \pm 6.97 \mathrm{ug} / 100 \mathrm{ml})$ compared to women without post-partum blues (30.14 $\pm 6.66 \mathrm{ug} / 100 \mathrm{ml}$ ) with $\mathrm{p}<0.00$.

Table 4. Analysis of $t$ test of the relationship between cortisol level with the incidence of postpartum blues

\begin{tabular}{lccccc}
\hline \multirow{2}{*}{$\begin{array}{c}\text { Post partum } \\
\text { blues }\end{array}$} & \multicolumn{2}{c}{ Cortisol } & $\mathrm{p}$ & $\mathrm{CI}$ \\
\cline { 2 - 3 } & Mean & $\mathrm{SD}$ & & \\
\hline Present & 42.90 & 6.97 & & $0.00^{*}$ & $7.639-17.878$ \\
Not present & 30.14 & 6.66 & & & \\
\hline
\end{tabular}

\section{DISCUSSION}

Stimulation in protracted labor could have an important role as a stressor which results from psychological changes in perception of post-partum patients. Stressors could also come from the situations in delivery room (Curry, 2008). Stress will excite the HPA axis which results in the release of cortisol, an agent suggested in the role of development of post-partum blues.

The results in this study showed in table 1 that the characteristcs of both groups were homogeneous, showing that no significant differences exist between the two groups. In table 2, the mean level of cortisol in stimulated labor were higher $(40,29 \pm 5.59 \mathrm{ug} / 100 \mathrm{ml})$ compared to normal labor $(33.59 \pm 11.17 \mathrm{ug} / 100 \mathrm{ml})$ with $\mathrm{p}=0,047(<0,05)$, which showed statistically that there was a significant difference in the mean level of cortisol that is not caused by chance.

The result of this study was supported by the notion that in stressful conditions, the HPA axis is down-regulated with negative feedback mechanism. Hypersecretion of corticotropin-releasing factor (CRF) by the hypothalamus induces the release of adrenocorticotropin hormone (ACTH) from the pituitary. The hormone ACTH will then interact with receptors in adrenocortical cells and cause the release of cortisol from the adrenal glands. The release of cortisol into the circulation has several effects, including metabolic effects (increased of blood glucose level). Negative feedback mechanism of cortisol to hypothalamus, pituitary and the immune system may happen as the plasma cortisol level rises. This could cause continuous HPA axis activation and continuous release of cortisol from the adrenal cortex, and thus the plasma cortisol level remain high. Cortisol receptors will become sensitized and cause an increase in the activity of pro-inflammatory cytokines and disturbance in neurotransmission (Zonana, 2005).

Post-partum blues is a temporary depression which is experienced by many new mothers because of the changes in hormonal levels and new perceived 
responsibilities. This condition may happen in the third to the tenth day post-labor, commonly after the patient has left the hospital. If this condition continues after two weeks, then it may mark more severe conditions such as depression or post-partum psychosis. These conditions should not be taken lightly because the subsequent effects are more complex (Elizabeth, 2008; Mary, 2012; Anderson, 2013).

The suspected primary factor in development of postpartum blues is the biological factor, which include hormonal factors, caused by sudden changes of certain hormone levels of progesterone, estrogen, thyroid hormones, endorphines, cortisol and prolactine which may have certain effects.

Post-partum blues could be a first symptom or mild symptom of post-partum depression. The American College of Obstetrics and Gynecology recommended screening of post-partum women who have risk factors in developing post-partum depression. The condition can be measured using the Blues Questionnaire which was based on the theory from Kennerley and Gath. The questionnaire contained 28 items about post-partum blue symptoms with the answer of yes or no, scored 1 and 0 , respectively. Someone is diagnosed with postpartum blues if found to have 12 symptoms in the questionnaire. Blues Questionnaire is a systematic measurement tool to assess post-partum blues and it has been validated (Priyastiwi, 2009).

In this study, first the subjects were asked to fill the LMMPI questionnaire, which contains 15 items answered with "yes" or "no" correlating to the choice which were most suitable. The subjects which answered "no" in < 10 items were included in the study. And then the subjects were asked to fill the Blues Questionnaire, and then the data were gathered and analyzed.

In table 3, it was shown the differences in incidence between the two groups, stimulated labor and normal labor, in which the stimulated labor group had an increased post-partum blues 5,5 times more compared to the normal labor group $(p=0,028)$. These results were consistent with Handerson (2007), which reported that intervention in delivery, such as stimulated induction or equipment assisted could increase post-partum stress, reduce the patient's trust and also increased incidence of post-partum blues.

In table 4, it was shown that mean cortisol level in the group with post-partum blues were significantly higher $(42,9 \pm 6.97 \mathrm{ug} / 100 \mathrm{ml})$ compared to the group without post-partum blues $(30,14 \pm 6.66 \mathrm{ug} / 100 \mathrm{ml})$, with $\mathrm{p}<0.00$. These results were consistent with Curry (2008), in which it was reported that stimulated induction in labor causes unnatural continuous contraction of the uterus, this will cause the head of the fetus to oscillate up and down in its route to labor, which cause increased pressure of the cervix. This condition will induce the posterior hypophysis to produce more oxytocin, which further excite uterine wall contraction and cause considerable pain. The pain is also a stressor which induces the activation of the HPA axis, which stimulates the increased release of cortisol, and subsequently increases the incidence of post-partum blues.

\section{CONCLUSION}

There was significant relationship between stimulation in protrated labor that increases cortisol serum level and post-partum blues incidence. Counseling of the patients and family in order to routinely attend ante natal care (ANC) is important to monitor and reduce risk factors related to complications in pregnancy, including the psychological effects. This needs to be done to minimize complications which indicate the necessity of stimulated labor induction.

\section{ACKNOWLEDGEMENT}

Our deepest gratitude to the patients who were willing to participate as subjects in this study.

\section{REFERENCES}

Anderson G, Maes M. 2013. Post-partum depression: psychoneuroimmunological underpinnings and treatment. Neuropsychiatric Disease and Treatment. 2013;9:277-287. doi:10.2147/NDT.S25320.

Bobak, I.M., Lowdermilk, D.L., Jensen, M.D. 1994: Maternity Nursing. Missouri: The C.V. Mosby Company. 480-665

Elizabeth J, Corwin, and Kathleen. 2008. The psychoneuroimmunologyof post-partum Depression. Journal of Women's Health. Vol 17, No. 9.

Faisal-Cury, A., Menezes, P.R., Tedesco, J.J.A., Kahalle, S. and Zugaib, M.2008 Maternity "blues": Prevalence and risk Factors. The Spanish Journal of Psychology, vol 11, No.2, 593-599.

Henderson and Jones. 2006. Buku ajar konsepkebidanan (Essential Midwifery). Alih bahasa Ria Anjarwati. Jakarta: EGC

Marshall F, 2004. Mengatasi Depresi Pasca Melahirkan. Jakarta: Arcan, pp:24-28

Mary E dan Coussons. 2012. The Psychoneuroimmunology of stres inpregnancy. Departement of Psychology University of Colorado Danver. 
PriyastiwiN. 2009. Gambaran Post-partum Blues pada Wanita Post Sectio Caesarea di RS PKU Muhammadiyah Yogyakarta dan RSUP dr Soeradji Tirtonegoro Klaten. FK UGM: Yogyakarta. Tidak diterbitkan Reeder S.J., Martin L.L., Koniak D. 1997: Maternity Nursing, Eighteenth Edition. Philadelphia: LippincottRaven Publishers. 1047.
Suhemi, A.B., 2009: Buku Acuan Nasional (Pelayanan Kesehatan Maternal dan Neonatal), JNPKK POGI, Jakarta. 495.

Shinaga, shinta, Hadi, P. 2006. Depresi dan Solusinya. Yogyakarta: Tugu.

Zonana J, Gorman J.M. 2005. The neurobiology of postpartum depression. CNS Spectr. 2005 Oct;10(10):792-9, 805. 